\title{
Analisis Polimorfisme DNA Ikan Gabus (Channa striata) Berbeda Ukuran Menggunakan Teknik RAPD
}

\author{
Analysis of DNA Polymorphism on Different Size of Snakehead Fish \\ (Channa striata) Using RAPD Technique
}

\author{
Ahmad Hanif Pranoto Utomo ${ }^{1}$, Taufik Budhi Pramono ${ }^{2}$, Hary Tjahja Soedibya ${ }^{3}$, \\ Purnama Sukardi $^{4}$, Hamdan Syakuri ${ }^{5^{*}}$ \\ 1,2,3,4,5 Program Studi Akuakultur, Fakultas Perikanan dan Ilmu Kelautan, Universitas \\ Jenderal Soedirman \\ *corr-author: hamdan.syakuri@unsoed.ac.id
}

\begin{abstract}
ABSTRAK
Seleksi genetik perlu dilakukan pada ikan gabus (Channa striata) yang potensial dikembangkan sebagai komoditas akuakultur di Indonesia. Teknik Random Amplified Polymorphic DNA (RAPD) umum digunakan untuk mengetahui polimorfisme DNA yang dikaitkan dengan ciri fenotip suatu organisme. Penelitian ini bertujuan untuk mengetahui polimorfisme DNA ikan gabus (Channa striata) ukuran berbeda dengan menggunakan teknik RAPD. Sampel ikan dari sepasang induk dikelompokkan berdasarkan berat menjadi tiga kelompok: kecil (2,26-3,00 g), sedang (3,01-3,75 g), dan besar (3,76-4,50 g). Sampel DNA diisolasi dari lima individu per kelompok ukuran. Amplifikasi DNA dilakukan menggunakan tiga primer RAPD (OPA-02, OPA04, OPA-07) dan hasilnya dianalisis menggunakan software PyElph. Sebagai tambahan, analisis Truss morfometrik dilakukan pada ketiga kelompok ikan tersebut. Hasil penelitian menunjukkan bahwa sebagian besar fragmen DNA bersifat monomorfik. Beberapa fragmen DNA bersifat polimorfik, namun tidak terkait dengan kelompok ukurannya. Percabangan pada hasil analisis filogenetik tidak mencerminkan kelompok ukuran ikan. Selain itu, tiga karakter morfometrik Truss (A2, A6 dan C3) dapat digunakan sebagai penanda kelompok ukuran berat yang berbeda pada ikan gabus.
\end{abstract}

Kata kunci: Ikan gabus (Channa striata), Polimorfisme DNA, RAPD

\begin{abstract}
Genetic selection needs to be done on snakehead fish (Channa striata) which has the potential to be developed as an aquaculture commodity in Indonesia. The Random Amplified Polymorphic DNA (RAPD) technique is commonly used to determine DNA polymorphisms associated with the phenotypic characteristics of an organism. This study aimed at determining the DNA polymorphism of different sizes of snakehead fish (Channa striata) using the RAPD technique. Fish samples from a pair of broodstock were grouped by weight into three groups: small (2.26-3.00 g), medium (3.01-3.75 g), and large (3.76-4.50 g).. DNA samples were isolated from five individuals per size group. Amplification of DNA was performed using three RAPD primers (OPA-02, OPA-04, OPA-07) and the results were analyzed using PyElph software. In addition,
\end{abstract}

(Analisis Polimorfisme DNA Ikan Gabus. Ahmad Hanif Pranoto 
morphometric Truss analysis was performed on all three groups of fish. The results showed that most of the DNA fragments were monomorphic. Some DNA fragments are polymorphic, but not related to size group of the fish. The branching on the results of phylogenetic analysis did not reflect the size of the fish groups. In addition, three Truss morphometric characters (A2, A6 and C3) can be used to mark different size (weight) groups in snakehead fish.

Keywords: Snakehead (Channa striata), DNA Polymorphism, RAPD

\section{PENDAHULUAN}

Sejak lama dinilai berpotensi untuk berkembang menjadi komoditas akuakultur, Ikan gabus (Channa striata) memiliki beberapa keunggulan (Kok, 1982). Jenis ikan ini memiliki nilai ekonomis tinggi dan permintaan pasar yang tinggi, serta memiliki toleransi terhadap kepadatan yang tinggi (Ath-thar et al., 2017). Penurunan populasi ikan gabus di alam menjadi dasar untuk meningkatkan produktivitas melalui kegiatan akuakultur. Seleksi strain unggul menjadi tahapan penting dalam mengembangkan ikan gabus menjadi komoditas akuakultur.

Laju pertumbuhan merupakan salah satu karakter penting dalam seleksi untuk menghasilkan strain ikan yang unggul. Seleksi ikan berdasarkan laju pertumbuhan dapat dilakukan dengan menggunakan ikan dari satu cohort untuk dikelompokkan berdasarkan ukuran yang berbeda, baik ukuran panjang maupun berat. Strain unggul kemudian dikembangkan dari kelompok ikan berukuran besar yang menandakan laju pertumbuhan yang lebih baik. Gustiano et al., (2013) menyatakan bahwa seleksi ikan berdasarkan ukuran dilakukan dengan cara mengelompokkan ikan sesuai dengan kelasnya. Untuk kelas induk ikan betina dan jantan masing-masing dikelompokkan menjadi 3 kelas yang terdiri dari kelas laju pertumbuhan tinggi, normal dan lambat. Induk-induk tersebut digunakan sebagai materi dalam seleksi yang dilakukan. Seleksi ikan yang memiliki laju pertumbuhan yang cepat juga dapat dilakukan dengan menggunakan marka molekuler berdasarkan analisis polimorfisme DNA.

Polimorfisme DNA dapat berfungsi sebagai penanda molekuler ikan yang memiliki laju pertumbuhan tinggi. Polimorfisme DNA dapat dianalisis dengan menggunakan teknik Random Amplification Polymorphic DNA (RAPD) (Williams et al., 1990). Penanda pada RAPD dapat mendeteksi polimorfisme DNA tingkat tinggi dan menghasilkan penanda genetik yang baik. Beberapa penelitian menunjukkan hasil bahwa analisis RAPD dapat digunakan untuk membedakan antar populasi pada ikan gabus (Channa striata) (Gustiano et al., 2013); Melanotaaenia ajamaruensis (Hayuningtyas et al., 2018); dan Barbonymus schwanenfeldii (Kusmini et al., 2017). Nursida (2011) menunjukkan bahwa terdapat perbedaan pola pita DNA hasil teknik RAPD antara ikan kerapu macan yang tahan dan rentan terhadap bakteri Vibrio alginolitycus serta terhadap salinitas yang berbeda. Teknik ini juga telah digunakan untuk menentukan marker genetik ikan nila (Ahmed \& Ali, 2004) dan ikan lele (Adesola et al., 2020; Awodiran \& Afolabi, 2018; Danish \& Singh, 2018; Ikpeme et al., 2015; Popoola et al., 2014).

Perkembangan budidaya ikan gabus perlu didukung upaya seleksi untuk memperoleh strain yang tumbuh cepat. Polimorfisme DNA dapat digunakan untuk membedakan ikan yang memiliki ukuran berbeda. Polimorfisme DNA dapat dianalisis dengan menggunakan teknik RAPD. Teknik ini dapat digunakan untuk mengetahui perbedaan polimorfisme DNA dari 3 kelompok ikan, yaitu kelompok yang memiliki 
ukuran besar, sedang dan kecil. Sehingga teknik ini dapat digunakan untuk menemukan penanda molekuler untuk ikan dengan ukuran yang berbeda. Tujuan dari penelitian ini yaitu untuk mengetahui polimorfisme DNA ikan gabus (Channa striata) dengan ukuran berat yang berbeda menggunakan teknik RAPD.

\section{METODE}

Metode yang digunakan pada penelitian ini menggunakan metode observasi. Pengambilan objek penelitian ini dengan cara mengambil langsung ke kolam pemeliharaan ikan gabus dari pembudidaya ikan di Sumpiuh. Selanjutnya objek penelitian dibawa ke Laboratorium Riset Fakultas Perikanan dan Ilmu Kelautan, Universitas Jenderal Soedirman. Ikan kemudian dikelompokkan berdasarkan berat. Sampel DNA diambil dari setiap kelompok sebanyak lima ekor untuk digunakan dalam analisis polimorfisme dengan menggunakan teknik RAPD. Analisis Truss morfometrik dilakukan sebagai data tambahan untuk mengetahui perbedaan antar kelompok.

\section{Sampel Ikan dan Pengelompokkan}

Sampel ikan sebanyak 50 ekor diambil dari satu populasi yang dihasilkan dari sepasang induk pada satu periode pemijahan. Ikan dibawa dari tempat pembenihan menggunakan metode transportasi basah dengan kantong plastik kapasitas 10 liter yang berisi air $1 / 3$ bagian dan $2 / 3$ bagian berisi oksigen. Ikan kemudian diseleksi dan dikelompokkan menjadi tiga kelompok, yaitu yaitu ukuran 2,26-3,00 g (kecil), ukuran 3,01-3,75 g (sedang) dan ukuran 3,76-4,50 g (besar). Lima ekor ikan dari setiap kelompok kemudian dipilih secara acak untuk analisis selanjutnya.

\section{Ekstraksi DNA}

Sampel DNA diekstraksi dari sirip ekor ikan gabus (Channa striata) dengan menggunakan Genomic DNA Mini Kit (Tissue, Geneaid) sesuai dengan petunjuk. Sirip ekor dipotong dari setiap sampel ikan, diambil sebanyak sekitar $30 \mathrm{mg}$ dan kemudian dimasukkan ke dalam microtube 1,5 ml. Jaringan dihaluskan dengan micropestle, sebanyak $200 \mu \mathrm{L}$ GT Buffer ditambahkan ke tube dan dihomogenkan. Sebanyak $20 \mu \mathrm{L}$ Proteinase K kemudian ditambahkan ke dalam tube sampel dan dihomogenkan dengan vortexing. Sampel diinkubasi pada water bath dengan suhu $60^{\circ} \mathrm{C}$ selama 30 menit. Selama diinkubasi, sampel dihomogenkan setiap 5 menit sekali. Pada tahap lisis, sebanyak $200 \mu \mathrm{L}$ GBT Buffer ditambahkan dan dihomogenkan dengan vortexing. Sampel diinkubasi kembali pada suhu $60^{\circ} \mathrm{C}$ selama 20 menit supaya lisis sempurna. Jika terdapat bagian sampel yang tidak lisis maka dilakukan sentrifuse kembali selama 2 menit pada 14-16000 x g dan supernatan dipindahkan ke microtube 1,5 ml yang baru. Sebanyak 200 $\mu \mathrm{L}$ ethanol absolut ditambahkan kemudian divortex dan spindown selama 10 detik. GS Column disiapkan dalam $2 \mathrm{ml}$ collection tube. Sampel selanjutnya dipindahkan ke dalam GS Column kemudian disentrifuse pada 14-16000 x g selama 2 menit. Collection tube dibuang kemudian GS Column dipindahkan ke $2 \mathrm{ml}$ collection tube yang baru. Pencucian dilakukan dengan menambahkan $400 \mu \mathrm{L}$ W1 buffer ke dalam GS Column kemudian disentrifuse pada 14-16000 x g selama 30 detik. Filtrat dibuang dan GS Column ditempatkan kembali pada $2 \mathrm{ml}$ collection tube. Sebanyak $600 \mu \mathrm{L}$ Wash Buffer kemudian ditambahkan ke GS Column, kemudian disentrifuse pada 14-16000 x g selama 30 detik. Filtrat dibuang kemudian GS Column diletakkan kembali pada $2 \mathrm{ml}$ collection tube. Collection tube disentrifuse selama 3 menit pada 14-16000 x g. Pada tahap akhir adalah DNA elution, GS Column dipindahkan ke microtube $1,5 \mathrm{ml}$. Sebanyak $100 \mu \mathrm{L}$ pre- 
heated elution buffer ditambahkan ke bagian tengah GS column dan sampel diinkubasi pada suhu ruang selama 5 menit. Sentrifuse dilakukan selama 30 detik pada 14-16000 x g dan sampel DNA disimpan pada suhu $-20^{\circ} \mathrm{C}$ sampai digunakan.

\section{Analisis Polimorfisme DNA}

Analisis polimorfisme DNA dilakukan dengan 3 tahapan, yaitu amplifikasi DNA, elektroforesis dan analisis polimorfisme. Tahapan awal amplifikasi DNA dilakukan menggunakan teknik RAPD dengan tiga primer, yaitu OPA-02, OPA-04 dan OPA-07 (Tabel 1). Amplifikasi dilakukan dengan volume $25 \mu \mathrm{L}$ yang terdiri atas $2 \mu \mathrm{L}$ DNA template (sampel) hasil isolasi, $2 \mu \mathrm{L}$ primer, $8,5 \mu \mathrm{L}$ distilled water dan dicampur $12,5 \mu \mathrm{L}$ My Taq ${ }^{\circledR}$ HS Mix (Bioline) (Tabel 2). Program PCR yang dijalankan ditampilkan pada

Tabel 3.

Tabel 1. Primer RAPD yang digunakan dalam penelitian ini

\begin{tabular}{ccc}
\hline Primer Kode & Sekuens & Referensi \\
\hline OPA-02 & TGCCGAGCTG & \\
OPA-04 & AATCGGGCTG & Gustiano et al., 2013 \\
OPA-07 & GAAACGGGTG & \\
\hline
\end{tabular}

Tabel 2. Komposisi reagen PCR RAPD yang digunakan dalam penelitian ini

\begin{tabular}{clc}
\hline No. & Bahan & Volume $(\mu \mathrm{L})$ \\
\hline 1. & DNA template (sampel) & 2 \\
2. & Primer & 2 \\
3. & Distilled water & 8,5 \\
4. & My Taq HS mix & 12,5 \\
\hline
\end{tabular}

Tabel 3. Program PCR RAPD yang digunakan dalam penelitian ini

\begin{tabular}{cccc}
\hline Step & Temperatur & Waktu & Jumlah \\
\hline Predenaturasi & $94^{\circ} \mathrm{C}$ & 2 menit & 1 \\
Denaturasi & $94^{\circ} \mathrm{C}$ & 1 menit & 35 siklus \\
Annealing & $36^{\circ} \mathrm{C}$ & 1 menit & \\
Elongasi & $72^{\circ} \mathrm{C}$ & 2 menit & 1 \\
Elongasi akhir & $72^{\circ} \mathrm{C}$ & 7 menit & 1 \\
\hline
\end{tabular}

Tahapan kedua yaitu elektroforesis. Tahap ini dilakukan menggunakan gel agarose $1,5 \%$ dalam larutan TBE 1x. Gel agarose dibuat menggunakan bubuk agarose sebanyak $1,2 \mathrm{~g}$ dengan dicampurkan ke dalam larutan TBE buffer 10x sebanyak $8 \mathrm{ml}$ dan larutan akuades sebanyak $72 \mathrm{ml}$. Kemudian campuran agarose tersebut dipanaskan dengan microwave hingga mendidih. Gel agarose didiamkan pada suhu ruang hingga hangat kuku dan ditambahkan $5 \mu \mathrm{L}$ Sybr safe gel staining. Cetakan gel agarose disiapkan dan dipasangi sisir. Gel agarose dituang pada cetakan yang telah disiapkan hingga temperatur ruang selama \pm 30 menit. Sisir dilepas dari gel agarose dan selanjutnya gel agarose diletakkan pada chamber elektroforesis. Larutan TBE buffer $1 \mathrm{x}$ dituang hingga menggenangi permukaan gel agarose. Hasil PCR RAPD dimasukkan ke dalam sumuran. Chamber elektroforesis ditutup dan dilakukan elektroforesis selama 45 menit pada tegangan 125 volt. Setelah itu gel agarose diambil dengan hati-hati. Langkah terakhir 
adalah visualisasi hasil elektroforesis menggunakan UV transilluminator dan kemudian didokumentasikan dengan kamera digital.

\section{Analisis Truss morfometrik}

Data rasio ukuran dianalisis menggunakan analisis pengelompokan untuk mengevaluasi keragaman pertumbuhan ikan gabus. Analisis keragaman morfologis dilakukan secara deskriptif dengan membandingkan nilai koefisien keragaman (CV) menurut Singh \& Chaudhary (1979). Karakteristik Truss morfometrik yang diamati sesuai titik Trussnya mengacu pada (

Gambar 1) dan deskripsi titik Trussnya sesuai dengan (Tabel 4). Analisis Truss morfometrik menggunakan dua metode yaitu, metode manual langsung mengukur menggunakan penggaris dan metode digital menggunakan aplikasi ImageJ.

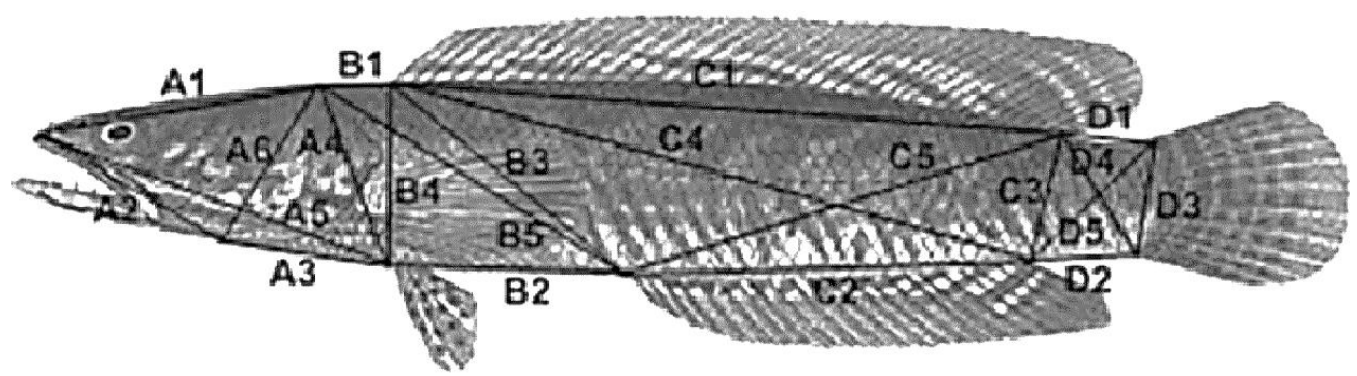

Gambar 1. Pengukuran Karakter Truss Morfometrik Ikan Gabus (Channa striata) (Sumber: Gustiano et al., 2013)

Tabel 4. Deskripsi 21 karakter Truss Morfometrik Ikan Gabus (Channa striata) (Sumber: Gustiano et al., 2013)

\begin{tabular}{llll}
\hline No & Bagian Truss & Kode & Deskripsi Jarak \\
\hline 1 & Kepala & A1 & Ujung mulut bagian atas - bagian akhir tulang kepala \\
2 & & A2 & Ujung mulut bagian atas - ujung bawah operculum \\
3 & & A3 & Ujung bawah operculum - awal sirip perut \\
4 & & A4 & Bagian akhir tulang kepala - awal sirip perut \\
5 & & A5 & Ujung mulut bagian atas - awal sirip perut \\
6 & & A6 & Ujung bawah operculum - bagian akhir tulang kepala \\
\hline 7 & Tubuh Tengah & B1 & Bagian akhir tulang kepala - awal sirip punggung \\
8 & & B2 & Awal sirip perut - awal sirip anal \\
9 & & B3 & Awal sirip punggung - awal sirip anal \\
10 & & B4 & Awal sirip perut - awal sirip punggung \\
11 & & B5 & Bagian akhir tulang kepala - awal sirip anal \\
\hline 12 & Tubuh Belakang & C1 & Awal sirip punggung- akhir sirip punggung \\
13 & & C2 & Awal sirip anal - akhir sirip anal \\
14 & & C3 & Akhir sirip punggung - akhir sirip anal \\
15 & & C4 & Awal sirip punggung - akhir sirip anal \\
16 & & C5 & Awal sirip anal - akhir sirip punggung \\
\hline 17 & Pangkal ekor & D1 & Akhir sirip punggung - awal sirip ekor atas \\
18 & & D2 & Akhir sirip anal - awal sirip ekor bawah \\
19 & & D3 & Awal sirip ekor atas - awal sirip ekor bawah \\
20 & & D4 & Akhir sirip punggung - awal sirip ekor bawah \\
21 & & D5 & Akhir sirip anal - awal sirip ekor atas \\
\hline
\end{tabular}

(Analisis Polimorfisme DNA Ikan Gabus. Ahmad Hanif Pranoto 


\section{Analisis Data}

Data polimorfisme DNA berupa gambar pita DNA hasil RAPD dianalisis menggunakan software PyElph (Pavel and Vasile, 2012). Tahapan analisis menggunakan software tersebut meliputi penentuan lajur, deteksi pita DNA, pengelompokan pita DNA, dan pembentukan pohon filogenetik. Pita DNA marker digunakan sebagai outgroup dalam pembentukan pohon filogenetik. Data Truss morfometrik dianalisis varian (ANOVA) untuk mengetahui adanya perbedaan antar kelompok dan dilanjutkan dengan Uji Tukey.

\section{HASIL DAN PEMBAHASAN}

\section{Hasil RAPD Ikan Gabus Berbeda Ukuran}

Multi fragment DNA atau pita DNA berhasil diamplifikasi dengan dua dari tiga primer yang digunakan, yaitu OPA-02 dan OPA-04. Pengelompokkan pita DNA berdasarkan ukuran menunjukkan adanya pita DNA monomorfik dan pita DNA polimorfik (Gambar 2). Sebagian besar fragment DNA yang dihasilkan kedua primer tersebut bersifat monomorfik, yaitu fragment DNA yang ditemukan pada setiap sampel. Sebagian kecil fragment DNA bersifat polimorfik, yaitu fragment DNA yang tidak ditemukan pada setiap sampel (

Tabel 5). Primer OPA-04 menghasilkan lebih banyak pita polimorfik dibandingkan primer OPA-02. Pita DNA polimorfik tidak ditemukan secara spesifik pada kelompok ukuran tertentu. Primer OPA-02 menghasilkan satu (1) pita DNA polimorfik yang ditemukan pada satu sampel berukuran kecil dan dua sampel berukuran sedang. Dua pita DNA polimorfik yang dihasilkan oleh primer OPA-04 juga ditemukan pada beberapa kelompok ukuran yang berbeda. Hal ini menunjukkan jika pita DNA polimorfik tersebut tidak terkait dengan kelompok ukuran ikan. 


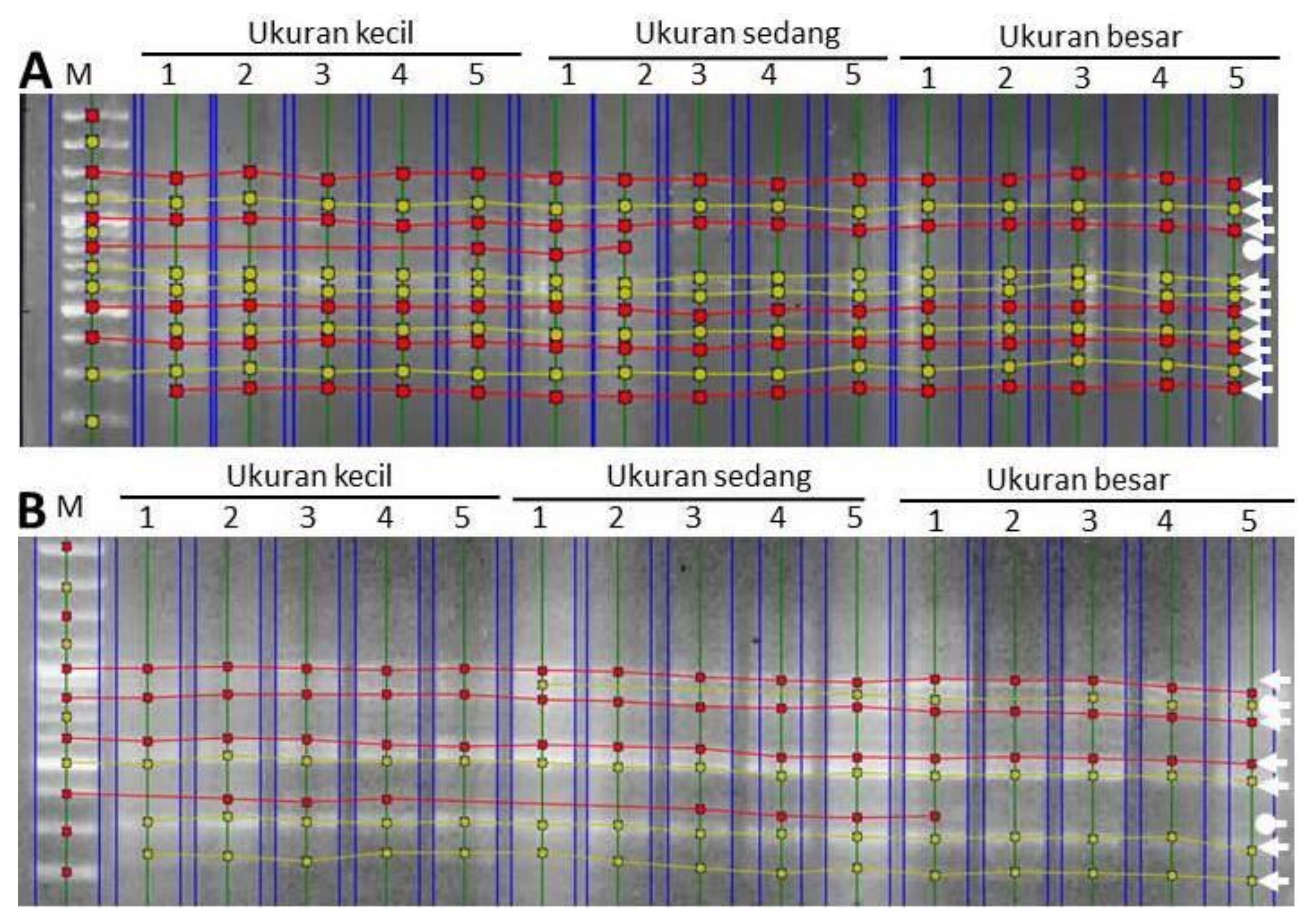

Gambar 2. Pengelompokkan pita DNA hasil RAPD sampel ikan gabus (Channa striata) ukuran berbeda menggunakan primer OPA-02 (A) dan primer OPA-04 (B) menunjukkan pita DNA monomorfik (panah) dan pita DNA polimorfik (panah oval). Ukuran ikan: Kecil (2,26 - 3,00 g), Sedang (3,01 - 3,75 g), dan Besar (3,76 4,50 g).

Tabel 5. Jumlah Pita DNA Ikan Gabus (Channa striata) hasil RAPD dengan Primer OPA-02 dan OPA-04

\begin{tabular}{cccc}
\hline Primer & Jumlah total pita & Jumlah pita monomorfik & Jumlah pita polimorfik \\
\hline OPA-02 & 11 & 10 & 1 \\
OPA-04 & 8 & 6 & 2 \\
\hline
\end{tabular}

Analisis filogenetik berdasarkan pita DNA yang teramplifikasi menggunakan primer OPA-02 membagi sampel ikan gabus menjadi dua cabang. Tiga sampel membentuk satu cabang, yaitu sampel sedang (2) dan kecil (1). Dua belas sampel lainnya membentuk satu cabang yang lain (Gambar 3A). Berdasarkan pita DNA hasil amplifikasi menggunakan primer OPA-04, sampel ikan gabus yang diteliti membentuk dua cabang yang masingmasing terdiri atas dua ranting (Gambar 3B). Sampel dari tiga ukuran berbeda terdistribusi secara acak dalam ranting-ranting tersebut. Hasil analisis filogenetik tersebut menunjukkan bahwa pola percabangan yang terjadi tidak selaras dengan pola pengelompokkan sampel ikan gabus berdasarkan ukuran (berat). Satu cabang atau ranting yang terbentuk terdiri atas sampel yang berasal dari dua atau tiga kelompok ukuran. Hal ini menunjukkan bahwa primer OPA-02 dan primer OPA-04 tidak dapat digunakan untuk membedakan kelompok ukuran yang berbeda pada ikan gabus.

(Analisis Polimorfisme DNA Ikan Gabus. Ahmad Hanif Pranoto 


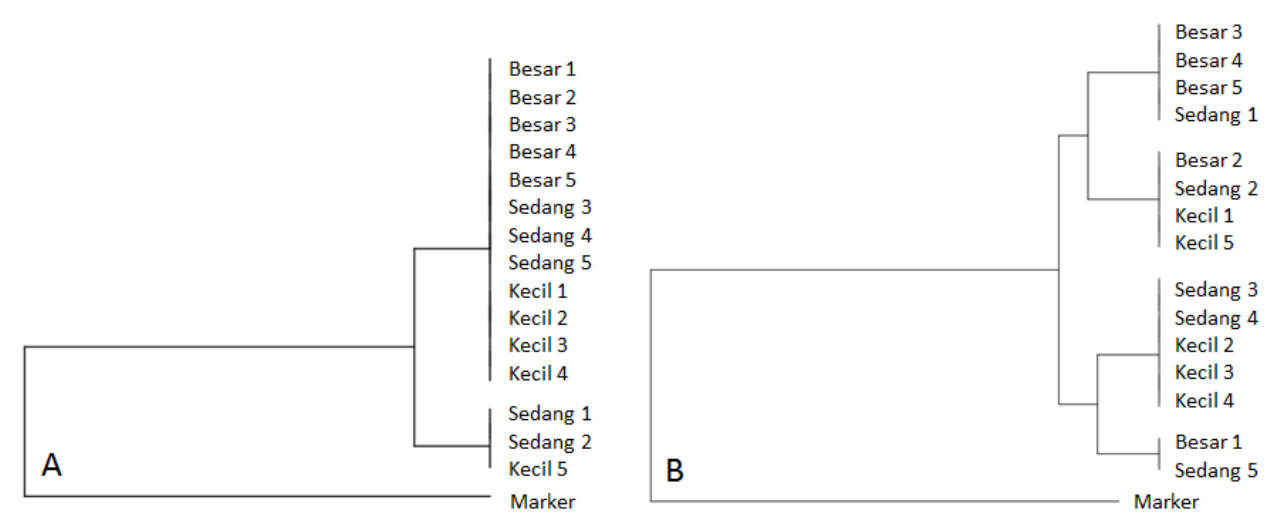

Gambar 3. Hasil analisis filogenetik hubungan kekerabatan antar kelompok ikan gabus (Channa striata) ukuran berbeda berdasarkan hasil RAPD dengan primer OPA-02 (A) dan primer OPA-04 (B). Tiga kelompok ukuran meliputi Kecil (2,26 3,00 g), Sedang (3,01 - 3,75 g), dan Besar (3,76 - 4,50 g).

Pita DNA polimorfik yang dihasilkan teknik RAPD dalam penelitian ini tidak terkait dengan pengelompokkan yang dilakukan. Satu pita DNA polimorfik yang dihasilkan primer OPA-02 dan dua pita DNA polimorfik yang dihasilkan primer OPA-04 kemungkinan merupakan penanda molekuler untuk ciri fenotip yang lain. Hasil RAPD menggunakan primer OPA-02 dan OPA-04 dalam penelitian ini belum menemukan penanda molekuler untuk perbedaan ukuran (berat) pada ikan gabus yang berasal dari satu pasang induk. Penanda molekuler DNA pada dasarnya merupakan segmen DNA spesifik yang dapat menunjukkan fragmen polimorfisme yang berbeda pada masingmasing individu dalam satu spesies. Fragmen polimorfik adalah gambaran pita DNA yang muncul pada ukuran tertentu, tetapi pada sampel lain tidak ditemukan pita DNA pada ukuran yang sama. Marka molekuler sensitif akan memberikan variasi alel yang berkaitan dengan fenotip dominan sesuai dengan hukum Mendel untuk karakter spesifik suatu spesies yang bermanfaat dalam program seleksi strain (Danish et al., 2012).

Marka molekuler selain menggunakan teknik RAPD dapat juga menggunakan alternatif teknik lainnya, salah satunya teknik RFLP. Teknik RFLP dapat digunakan karena dapat membedakan genom. Penentuan genom menggunakan teknik RFLP lebih sederhana dan lebih mudah dilakukan, hal ini karena primer yang digunakan bersifat universal sehingga amplifikasi yang dilakukan dapat lebih mudah dan efisien dalam segi waktunya (Ekasari et al., 2012).

\section{Truss Morfometrik Ikan Gabus Berbeda Ukuran}

Pengukuran truss morfometrik dilakukan terhadap 21 karakter pada tiga kelompok ikan gabus ukuran berbeda. Nilai rerata karakter truss morfometrik ikan gabus disajikan pada (

Tabel 6).

Berdasarkan karakter truss morfometrik dari tiga kelompok ikan gabus, terdapat beberapa karakter yang merupakan penciri dari ketiga kelompok ikan tersebut diantaranya kode A2 (Ujung mulut bagian atas - Ujung bawah operculum), A6 (Ujung bawah operculum - Bagian akhir tulang kepala), dan C3 (Akhir sirip punggung - Akhir 
sirip anal). Hal ini mengindikasikan bahwa ikan gabus dari ketiga kelompok terdapat beberapa perbedaan karakter truss morfometriknya $(\mathrm{P}<0,05)$. Hasil yang didapat dari karakter truss morfometrik menyebutkan bahwa pada karakter A2 dan C3 hanya ikan gabus ukuran besar yang berbeda nyata dari ikan gabus ukuran kecil. Kemudian pada karakter A6 ikan gabus ukuran besar berbeda nyata dengan ukuran sedang namun tidak berbeda nyata dengan ukuran kecil serta pada karakter A6 ikan gabus ukuran sedang juga berbeda nyata dengan ukuran kecil.

Uji signifikan dilakukan untuk mengetahui karakter yang dapat digunakan sebagai penciri dari suatu jenis ikan. Karakter Truss morfometrik yang berbeda pada ikan gabus diduga menunjukkan masing-masing individu ikan gabus telah terjadi variasi secara fenotip. Hal ini karena variasi fenotipe antar individu ikan gabus disebabkan oleh aspek biologi dan fisiologi ikan, efek maternal, pola makan, serta kompensasi pertumbuhan dan pemeliharaan bersama (communal stocking) yang dapat memengaruhi tingkat keragaman fenotipe pada populasi ikan gabus. Hasil pada penelitian ini sesuai dengan penelitian Radona et al., (2017) terhadap ikan tengadak yang mendapati nilai karakter Truss morfometrik tertinggi pada ukuran besar (G-0) dan pada ukuran sedang (G-1) tidak jauh nilai Truss morfometriknya dengan ukuran besar (G-0) serta pada ukuran kecil (G-2) nilai Truss morfometriknya sangat jauh dengan ukuran besar (G-0) dan ukuran sedang (G-1).

Tabel 6 Rerata karakter Truss-morfometrik ikan gabus (Channa striata) tiga kelompok ukuran berbeda

\begin{tabular}{|c|c|c|c|}
\hline $\begin{array}{c}\text { Karakter } \\
\text { morfometrik }\end{array}$ & $\operatorname{Kecil}(2,26-3,00 \mathrm{~g})$ & $\begin{array}{c}\text { Kelompok Ukuran } \\
\text { Sedang }(3,01-3,75 \mathrm{~g})\end{array}$ & $\operatorname{Besar}(3,76-4,50 \mathrm{~g})$ \\
\hline A1 & $0,23 \pm 0,014^{\mathrm{a}}$ & $0,23 \pm 0,194^{\mathrm{a}}$ & $0,20 \pm 0,164^{\mathrm{a}}$ \\
\hline $\mathrm{A} 2 *$ & $0,22 \pm 0,013^{b}$ & $0,20 \pm 0,089^{\mathrm{ab}}$ & $0,18 \pm 0,187^{\mathrm{a}}$ \\
\hline A3 & $0,19 \pm 0,017^{\mathrm{a}}$ & $0,19 \pm 0,228^{a}$ & $0,18 \pm 0,207^{\mathrm{a}}$ \\
\hline A4 & $0,22 \pm 0,018^{\mathrm{a}}$ & $0,21 \pm 0,100^{\mathrm{a}}$ & $0,22 \pm 0,181^{\mathrm{a}}$ \\
\hline A5 & $0,35 \pm 0,033^{\mathrm{a}}$ & $0,33 \pm 0,164^{\mathrm{a}}$ & $0,36 \pm 0,331^{\mathrm{a}}$ \\
\hline A6* & $0,22 \pm 0,018^{b}$ & $0,18 \pm 0,130^{\mathrm{a}}$ & $0,23 \pm 0,216^{b}$ \\
\hline $\mathrm{B} 1$ & $0,12 \pm 0,023^{\mathrm{a}}$ & $0,11 \pm 0,044^{\mathrm{a}}$ & $0,13 \pm 0,223^{a}$ \\
\hline B2 & $0,20 \pm 0,040^{\mathrm{a}}$ & $0,19 \pm 0,109^{a}$ & $0,22 \pm 0,130^{\mathrm{a}}$ \\
\hline B3 & $0,30 \pm 0,025^{\mathrm{a}}$ & $0,28 \pm 0,054^{\mathrm{a}}$ & $0,28 \pm 0,130^{\mathrm{a}}$ \\
\hline B4 & $0,15 \pm 0,014^{\mathrm{a}}$ & $0,15 \pm 0,151^{\mathrm{a}}$ & $0,15 \pm 0,083^{\mathrm{a}}$ \\
\hline B5 & $0,39 \pm 0,038^{a}$ & $0,35 \pm 0,070^{\mathrm{a}}$ & $0,39 \pm 0,320^{\mathrm{a}}$ \\
\hline $\mathrm{C} 1$ & $0,60 \pm 0,049^{a}$ & $0,57 \pm 0,268^{\mathrm{a}}$ & $0,59 \pm 0,350^{\mathrm{a}}$ \\
\hline $\mathrm{C} 2$ & $0,36 \pm 0,031^{\mathrm{a}}$ & $0,39 \pm 0,151^{\mathrm{a}}$ & $0,36 \pm 0,228^{a}$ \\
\hline $\mathrm{C} 3 *$ & $0,09 \pm 0,021^{\mathrm{a}}$ & $0,11 \pm 0,044^{b}$ & $0,11 \pm 0,109^{\mathrm{ab}}$ \\
\hline $\mathrm{C} 4$ & $0,59 \pm 0,048^{a}$ & $0,59 \pm 0,250^{\mathrm{a}}$ & $0,56 \pm 0,141^{\mathrm{a}}$ \\
\hline C5 & $0,41 \pm 0,037^{\mathrm{a}}$ & $0,37 \pm 0,308^{a}$ & $0,41 \pm 0,114^{\mathrm{a}}$ \\
\hline D1 & $0,07 \pm 0,013^{\mathrm{a}}$ & $0,09 \pm 0,130^{\mathrm{a}}$ & $0,09 \pm 0,230^{\mathrm{a}}$ \\
\hline D2 & $0,09 \pm 0,008^{a}$ & $0,10 \pm 0,089^{a}$ & $0,10 \pm 0,173^{\mathrm{a}}$ \\
\hline D3 & $0,10 \pm 0,009^{a}$ & $0,10 \pm 0,044^{\mathrm{a}}$ & $0,12 \pm 0,151^{\mathrm{a}}$ \\
\hline D4 & $0,12 \pm 0,008^{a}$ & $0,11 \pm 0,054^{\mathrm{a}}$ & $0,12 \pm 0,204^{\mathrm{a}}$ \\
\hline D5 & $0,15 \pm 0,017^{\mathrm{a}}$ & $0,15 \pm 0,083^{\mathrm{a}}$ & $0,14 \pm 0,122^{\mathrm{a}}$ \\
\hline
\end{tabular}

Keterangan : Data merupakan hasil rerata $(\mathrm{n}=5 ; \bar{x} \pm \mathrm{SD})$. Tanda * pada karakter Truss morfometrik menunjukkan adanya perbedaan nyata antar kelompok. Angka yang diikuti huruf kecil superscript yang berbeda menunjukkan perbedaan signifikan $(\mathrm{P}<0,05)$. 
Perbedaan pada keragaman genetik dapat meningkatkan jarak genetik antar populasi dan umumnya dapat digunakan sebagai pertimbangan dalam melakukan seleksi dan persilangan. Secara umum hasil pada penelitian sangat berbeda antara Truss morfometrik dengan PCR, pada hasil Truss morfometrik terdapat beberapa karakter yang dapat dijadikan penciri untuk seleksi strain ikan namun pada hasil PCR dengan menggunakan primer OPA-02 dan OPA-04 tidak terdapat pita DNA yang polimorfik untuk membedakan antar ukuran sehingga seleksi strain ikan menggunakan RAPD tidak tepat dilakukan (Radona et al., 2016).

\section{KESIMPULAN}

Polimorfisme DNA ikan Gabus (Channa striata) berdasarkan hasil RAPD menggunakan primer OPA-02 dan OPA-04 tidak berkaitan dengan perbedaan ukuran (berat). Sebagai tambahan, terdapat tiga karakter Truss morfometrik yang dapat membedakan ikan Gabus yang memiliki ukuran berat berbeda, yaitu A2, A6, dan C3. Penelitian lanjutan diperlukan untuk mendapatkan penanda molekuler untuk ikan Gabus yang memiliki laju pertumbuhan yang tinggi.

\section{UCAPAN TERIMA KASIH}

Terima kasih disampaikan kepada Fakultas Perikanan dan Ilmu Kelautan, Universitas Jenderal Soedirman untuk fasilitas laboratorium yang disediakan. Terima kasih juga disampaikan untuk Laboratorium Genetika Molekuler, Fakultas Biologi, Universitas Jenderal Soedirman untuk penggunaan mesin PCR. Penelitian ini adalah bagian dari tugas akhir atas nama Ahmad Hanif Pranoto Utomo.

\section{DAFTAR PUSTAKA}

Adesola, O.F., Awodiran, M.O., Olaleye, F., Awopetu, J.I., 2020. Genetic Characterization Based on RAPD-PCR in Cultured Strains of Clarias gariepinus ( Siluriformes : Clariidae ). Genet. Aquat. Org. 4, 81-88.

Ahmed, M.M.M., Ali, B.A., 2004. Application of RAPD markers in fish : Part I - some genera ( Tilapia , Sarotherodon and Oreochromis ) and species ( Oreochromis aureus and Oreochromis niloticus ) of Tilapia Application of RAPD markers in fish : Part I - some g. Int. J. Biotechnol. 6, 86-93. doi:10.1504/IJBT.2004.004615

Ath-thar, M.H.F., Gustiano, R., Kusmini, I.I., Prakoso, V.A., Putri, F.P., 2017. Induksi Hormonal Maturasi Gonad Ikan Gabus (Channa striata). J. Ris. Akuakultur 12, 920.

Awodiran, M., Afolabi, O., 2018. Genetic Diversity in Cultured and Wild Population of Clarias gariepinus ( Burchell , 1822 ) in Nigeria Using Random Amplified Polymorphic DNA ( RAPD ) and Microsatellite DNA. Fish. Aquac. J. 9, 247. doi:10.4172/2150-3508.1000247

Danish, M., Singh, I.J., 2018. Assessment of Genetic Diversity of Two Populations of Catfish Clarias batrachus L. Using Random Aamplified Polymorphic DNA ( RAPD ) Markers. J. Pharmacogn. Phytochem. 7, 2345-2352.

Danish, M., Singh, I.J., Giri, P., Singh, C.P., 2012. Molecular Characterization of Two Populations of Catfish Clarias batrachus L. Using Random Amplified Polymorphic DNA (RAPD) Markers. African J. Biotechnol. 11, 14217-14226.

Ekasari, T.W.D., Retnoningsih, A., Widianti, T., 2012. Analisis Keanekaragaman 
Kultivar Pisang Menggunakan Penanda PCR-RFLP Pada Internal Transcribed Spacer (ITS) DNA Ribosom. J. MIPA 35, 21-30.

Gustiano, R., Oktaviani, T., Soelistyowati, D.T., Kusmini, I.I., Wahyutomo, Huwoyon, G.H., 2013. Analisis Ragam Genotip RAPD dan Fenotip Truss Morfometrik pada Tiga Populasi Ikan Gabus [Channa striata (Bloch, 1793)]. Ber. Biol. 12, 325-333.

Hayuningtyas, E.P., Sinansari, S., Fahmi, M.R., Kusrini, E., Nur, B., 2018. Karakter Genotipe Tiga Populasi Ikan Rainbow Ajamaru (Melanotaenia ajamaruensis) dari Alam dan Budidaya Menggunakan RAPD. J. Ris. Akuakultur 13, 105-113.

Ikpeme, E.V., Udensi, O.U., Ekaluo, U.B., Kooffreh, M., 2015. Unveiling The Genetic Diversity in Clarias gariepinus ( Burchell , 1822 ) Using Random Amplified Polymorphic DNA ( RAPD ) Fingerprinting Technique. Asian J. Anim. Sci. 9, 187197. doi:10.3923/ajas.2015.187.197

Kok, L.W., 1982. Snakeheads Their Biology And Culture. Recent Adv. Aquac. 180-213.

Kusmini, I.I., Gustiano, R., Radona, D., Prakoso, V.A., Putri, F.P., Prihadi, T.H., 2017. Karakterisasi Fenotipe Dan Genotipe Tiga Populasi Ikan Tengadak (Barbonymus schwanenfeldii). J. Ris. Akuakultur 11, 207-216.

Nursida, N.F., 2011. Polimorfisme Ikan Kerapu Macan (Ephinephelus fuscoguttatus FORSSKÅL) yang Tahan Bakteri Vibrio alginolitycus dan Toleran Salinitas Rendah serta Salinitas Tinggi. Universitas Hasanuddin.

Popoola, O.M., Fasakin, E.A., Awopetu, J.I., 2014. Genetic Variability in Cultured and Wild Populations of Clarias gariepinus ( Osteichthys : Clariidae ) Using Random Amplified Polymorphic DNA ( RAPD ) Marker. Croat. J. Fish. 72, 5-11.

Radona, D., Kusmini, I.I., Fariduddin, M.H., 2017. Karakterisasi Meristik dan Morfometrik Tiga Generasi Ikan Tengadak Barbonymus schwanenfeldii Asal Kalimantan Barat, Indonesia. J. Ris. Akuakultur 12, 1-8.

Radona, D., Soelistyowati, D.T., Gustiano, R., Carman, O., Kusmini, I.I., Sundari, S., 2016. Ragam Genotipe Ikan Tengadak, Barbonymus schwanenfeldii(Bleeker 1854) Persilangan Populasi Jawa dan Kalimantan Berdasarkan RAPD. J. Ris. Akuakultur 11, 99-105.

Singh, R.K., Chaudhary, B.D., 1979. Biometrical Methods In Quantitative Genetic Analysis. Biometrical Methods Quant. Genet. Anal.

Williams, J.G.K., Kubelik, A.R., Livak, K.J., Rafalski, J.A., Tingey, S. V, 1990. DNA Polymorphisms Amplified by Arbitrary Primers are Useful as Genetic Markers. Nucleic Acids Res. 18, 6531-6535. 